\title{
Health Information Systems Use Model by Physicians in Developing Countries
}

\author{
Olugbenga Akeem Adenuga \\ School of Computing \\ University of South Africa \\ Johannesburg, South Africa
}

\author{
Ray Kekwaletswe \\ Department of Information Systems \\ University of the Witwatersrand \\ Johannesburg, South Africa
}

\begin{abstract}
In this paper, Health Information Systems (HIS) is presented to discuss factors that enhance physician's use of the application. The goal of the study is to develop a model and mathematically represent the model which could be used to optimise HIS use. The study adopts the Unified Theory of Acceptance and Use of Technology (UTAUT), which has been widely used in Information Systems (IS) research to study the behaviour of individuals that uses information technology. The theory is then extended with Self Efficacy theory in order to propose a research model for the use of health information systems (HIS). The variables in the proposed research model could be used to study the behaviour of physicians toward the use of the HIS application. The contribution of the study is in three perspectives, (i) theoretically; (ii) conceptually (iii) methodologically; and (iv) practically.
\end{abstract}

\section{Introduction}

The ubiquitous use of Information and Communication Technologies (ICT) in every facet of our professional and social lives is fascinating in most developing countries. Numerous uses of ICT among professionals saw its application in communication and information gathering. Healthcare, being one of the areas where ICT has seen a sharp increase in the use of applications is experiencing challenges owing to growing usage by healthcare professionals.

This study examine the difficulties experienced by health care professionals such as (Physicians, Nurses, Pharmacists, Physiotherapists, Laboratory Technicians and others) in the use of Health Information Systems (HIS) for health care delivery in developing countries. Therefore, this proposal will look at factors that hinder health care professionals in the use of ICTs in health care delivery. The observed context in this study is the Nigerian Primary Health Care (PHC) system. In the 2013 Ibrahim Index of African Governance (IIAG), a framework for assessing the delivery of public services in the continent ranked health care delivery in Nigeria 41 out of the 52 countries in Africa.

This study analytical model for assessing behavior of physicians toward the use of HIS in developing countries will identify a couple of HIS systems currently in operation within the South Western part of Nigeria (a region with the highest number of immigrant both from within and outside the country.

The analytical approach in this study evaluate latent growth model whereby specific structures of individual variables in a model change could be in linear, exponential or in quadratic form and many other mathematical forms. This approach is suitable when a theory guides the model, whereby the best fitting model is chosen based on fit statistics.

Various studies have examined the latent growth model in Structural Equation Models (SEM) [28][6][6] identifying factors in estimating latent interactions for predicting strategies for product indicators [14][27] as well as tools and methodologies that could enhance the successful use of the system [18]. In addition, some studies examined the methods or approaches used in HIS for effective usage of the system from the perspectives of patients. [16] The studies further examined different categories of approaches to the HIS system and different levels of HIS effectiveness in regional HIS. [13] It found that different categories of HIS users use the system for different medical or healthcare concerns.

Studies done so far in these premises highlighted some significant gaps, and these gaps need to be addressed. Firstly, the effective use of HIS has been studied from the perspectives of the patients. Not so many researches have looked into factors that could enhance healthcare professionals' usage of HIS [25][19]. Secondly, how HIS is used - from the perspective of the physician has not yet been thoroughly and empirically researched with respect to developing countries.

This paper proceeds to section 2 which gives an overview on the theoretical perspective while section 3 presents the proposed research model of physician's use of HIS. Section 4 discusses mathematical representation of the proposed research 
model of physician's HIS use and lastly section 5 concludes the paper.

Challenges and issues in the use of HIS have not been well addressed in the context of developing countries; most of the studies done so far have been on developed countries context. There is inadequate literature on HIS use from the perspectives of developing countries. Furthermore, the majority of studies done on HIS tend to look at patient's use of HIS with literature search yielding none published studies that focus physician's use of HIS. The proposed study aims to bridge that literature gap. The observed challenges has to do with the adoption, acceptance and use of HIS in developing countries; there is thus a need for a model for HIS use that may help unravel these challenges, by addressing how HIS may be used by physicians within the African context.

Studies done so far in these premises highlighted some significant gaps, and these gaps need to be addressed. Firstly, the effective use of HIS has been studied from the perspectives of the patients, few researches have looked into factors that could enhance health care professional's usage of HIS [25][19]. Secondly, the HIS usage factors from the perspective of physicians have not yet been thoroughly and empirically researched in developing countries' context of which Nigeria is unique and distinct from other contexts which heightens the need for the research. And lastly, there is no developed and empirically validated framework for assessing usage of HIS using a Structural Equation Modelling (SEM) analysis in the context of Nigerian health care environments.

These problems can be viewed from the following perspectives:

- $\quad$ Patients visiting the healthcare facilities are frustrated with the long queues.

- $\quad$ Physicians are frustrated because they have to attend to large number of patents.

- The government invested in HIS application but the effect of HIS application is not felt on healthcare service delivery.

The goal of this study is to develop a model to optimize HIS usage by physicians in developing countries.

The research objectives are:

1. To examine how HIS is used by physicians in a developing country.

2. To explore factors influencing HIS use by physicians.

3. To conceptualise a model for HIS use by physicians in developing countries.

4. To present mathematical representation for the conceptualised model.

\section{Theoretical perspective}

This section of the paper will be discussed by taking into consideration theories and models in the IS discipline that discuss behaviour towards the use of computers and information technology. The Technology Acceptance Model (TAM) [11], the Theory of Reasoned Action (TRA) [11], the Theory of Planned Behavior (TPB) [1] and the Self Efficacy [4] have been exploited in the IS literature to discuss the behaviour of users toward the use of ICT. The body of research based on these theoretical frameworks has produced some useful insights into the cognitive, affective and behavioural reactions of individuals to technology, and into the factors that influence these reactions [4]. [21] Illustrated, in each of the above theoretical frameworks, how behaviour towards the use of computers is viewed as the result of a set of beliefs about technology and a set of affective responses to the behaviour. In Innovation Diffusion research, beliefs are acknowledged by its perceived characteristics. In TAM, beliefs are characterised by perceived usefulness and ease of use. TPB sees beliefs by behavioural beliefs, outcome evaluations and by outcome expectations in the SCT. The net benefits that accrue from the use of the system according to [22] researches are from the continuous use of the system. The similarities in these models reflect a belief in the cognitive basis of behaviour.

The suggestion on TAM and the Diffusion of Innovations Perspectives [21] focuses almost exclusively on beliefs about a technology and the outcomes of using the technology, SCT and TPB. [9] In their study on perceived ease of use and perceived usefulness, included other beliefs which are independent of perceived outcomes and might influence behaviour. The TPB model incorporates the notion of Perceived Behavioral Control (PBC) as an independent influence on behaviour, recognising that there are circumstances in which behaviour might be expected to result in positive consequences, yet not be undertaken because of a perceived lack of ability to control the execution of the behaviour. PBC encompasses perceptions of resources and technology facilitating conditions, similar to those measured by others [23], as well as perceptions of ability or self-efficacy [24].

The results from the research based on the above theoretical frameworks provide useful insights into the reaction of the individual to the use of computer applications in an organisation. Previous studies [3] guaranteed that system use is a behaviour, of which the determinants are not well understood in IS research and that system use could best be explained 
by referring to an appropriate reference theory. This assertion showed in the following studies [3][9][26][25] which relied on TRA in their attempts to explain user behaviours. While TRA is very useful, it is somewhat incomplete. TRA has been widely tested but leaves aside factors that could also have influence on behavioural intentions and on behaviour itself [3].

Development and test of a theory of technological learning and usage explained personal computer usage and IS use by grounding their research models on TRA. However, a richer, theoretical framework was developed in the User Acceptance of Information Technology (UTAUT) [26]. While the theory of [11] considers all beliefs that a person has about an act or behaviour, [26] attempts to look into factors that control behavioural intention and use behaviour.

\subsection{Concept underlying the theoretical background}

The concept of self-efficacy, while representing a unique perception, is similar to a number of other motivational constructs such as effort-performanceexpectancy [12], locus of control, and self-esteem. The research work in [6] Self-Efficacy: The Exercise of Control, provides a detailed discussion of the similarities and differences between self-efficacy and these other motivational constructs.

[26] A review of the research on "The outcome of regional healthcare information systems in health care" provides explanation for the concept of individual acceptance of information technology as individual reactions to using information technologyintentions to use information technology-actual use of information technology. There is a causal relationship between the three concept was referred to by [26] as basic concept underlying user acceptance of technology.

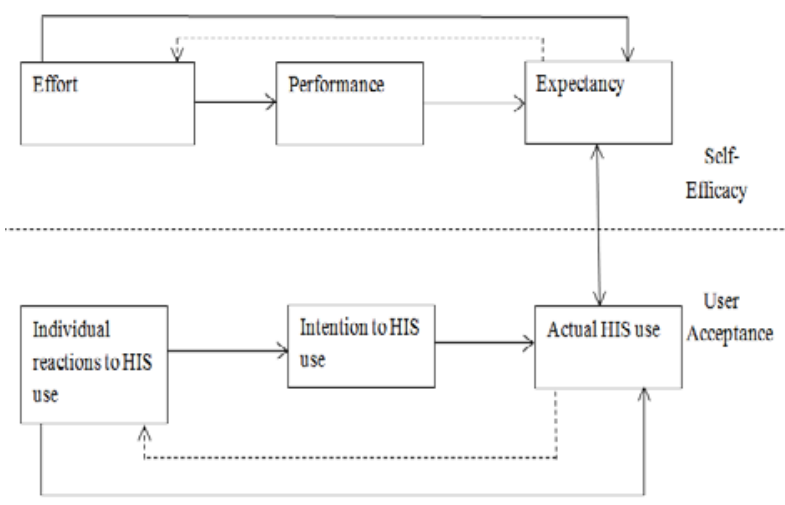

Figure 1: Concept behind Health Information Systems use

\section{Proposed model of physicians HIS use}

\subsection{Theoretical under pinning of the proposed model of HIS use}

This paper presents a model which is an extension of the [26] UTAUT model together with the SCT model[6]. The intention of the proposed model is to discuss the factors that influence the HIS usage by physicians in the developing countries.

The usage acceptance constructs are mainly adopted from [26]. UTAUT and self-efficacy constructs are influential in how physicians perceive the use of HIS is adopted from the SCT model proposed by [6]. The behavioural intention from the unified Theory of Acceptance and UTAUT model [26], is in the following: (1) performance expectancy, (2) effort expectancy, and (3) social influence. The behavioural intention assists in understanding of HIS use behaviour from the perspectives of physicians using the HIS and this enables us to determine factors which could motivate physician in the use of HIS.

\subsection{The proposed conceptual research model for HIS use}

The variables for the social influence construct in the model are subjective norms, subjective roles, subjective values and social situations. By including the social influence construct in the research model, the perceptions of the individual of subjective culture in using HIS were measured, as well as the effect of social situations on HIS use. The variables for the performance expectancy construct in this study consist of perceived usefulness, extrinsic motivation, job-fit, relative advantage, and outcome expectations. The effort expectancy construct in this study consists of perceived ease of use, complexity and ease of use of the HIS system. Consistent with the [26] UTAUT model, the variables for the facilitating conditions construct are perceived ease of use and complexity. The variables for the performance accomplishments and social persuasion are adopted from the Self Efficacy, [6]. The proposed research model of physician HIS use is presented in Figure 2. 


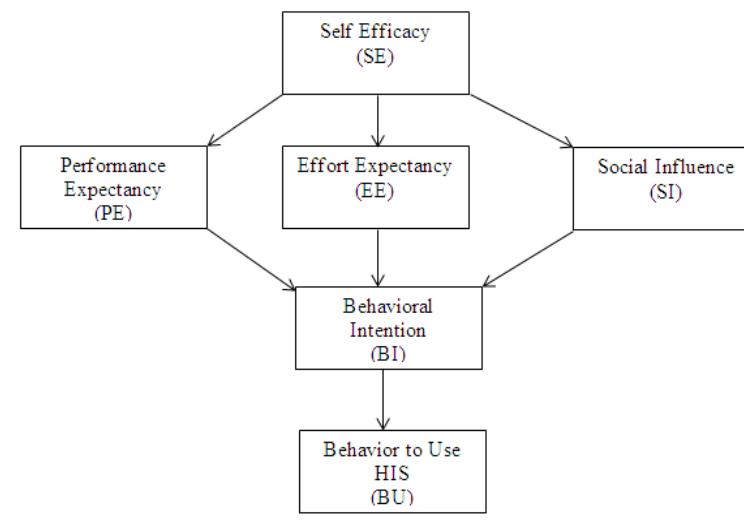

Figure 2. The proposed research model of physician HIS use

3.3. Mathematical representation of the proposed research model of physician HIS use

Evaluating the association between the variables is an important theoretical and empirical issue in information systems (IS), as well as in much other behavioural and social research. The two frequently used methods in evaluating the latent interactions between variables are the unconstrained approach and the latent moderated structural equations (LMS) approach. In order to show the association between variables in this study, the mathematical representation of the proposed research model of physician HIS use model is as shown here:

$$
\begin{aligned}
& S E=\beta_{1} P E+\beta_{2} E E+\beta_{3} S I+\varsigma_{1} \\
& P E=\beta_{4} S E+\beta_{5} B I+\varsigma_{2} \\
& S I=\beta_{6} S E+\beta_{7} B I+\varsigma_{3} \\
& E E=\beta_{8} S E+\beta_{9} B I+\varsigma_{4} \\
& B I=\beta_{10}+\beta_{11} E E+\beta_{12} S I+\varsigma_{5} \\
& B U=\beta_{13}+\varsigma_{6}
\end{aligned}
$$

The list of the endogenous variables in the vector form can be seen in the next column.

$$
Y=\left[\begin{array}{c}
S E \\
P E \\
S I \\
E E \\
B I \\
B U
\end{array}\right]
$$

The list of exogenous variables in vector form $X=(A M)$ and errors in vector form,

$$
\zeta=\left[\begin{array}{l}
\varsigma_{1} \\
\varsigma_{2} \\
\varsigma_{3} \\
\varsigma_{4} \\
\varsigma_{5} \\
\varsigma_{6}
\end{array}\right]
$$

Then this form two matrices of regression coefficients, or path coefficients, as they are called in SEM.

$B=$ the path from endogenous variables to endogenous variables

$B(1,2)=$ the coefficient of the path from $Y_{2}$ to $Y_{1}$ (a parameter if paths exists, 0 if no path exists)

$\Gamma=B(2,1)=$ the coefficient of the path $X_{1}$ to $Y_{2}$

Therefore, the mathematical model for HIS use by physician is represented by

$$
Y=B Y+\Gamma X+E
$$

where

$$
B=\left[\begin{array}{cccc}
0 & \beta_{2} & 0 & 0 \\
\beta_{4} & 0 & 0 & 0 \\
\beta_{6} & \beta_{7} & 0 & 0 \\
\beta_{8} & \beta_{9} & 0 & 0 \\
\beta_{10} & \beta_{11} & \beta_{12} & 0 \\
0 & 0 & \beta_{13} & 0
\end{array}\right] \text { and }
$$




$$
\Gamma=\left[\begin{array}{c}
\beta_{1} \\
\beta_{5} \\
0 \\
0 \\
0 \\
0
\end{array}\right]
$$

$Y=$ the vector of the endogenous variables

$X=$ the vector of the exogenous variables

$B=$ the matrix containing path coefficients

$B_{(i, j)}=$ the coefficient of the path from endogenous node $j$ to endogenous node $i$

$\Gamma=$ The matrix containing the coefficients of paths from exogenous variables to endogenous variables

$\Gamma_{(i, j)}=$ The coefficient of the path from exogenous node $j$ to endogenous node $i$

$\varsigma=$ The vector containing the error variables in the path equation

To accommodate for null hypothesis in Structural Equation Model (SEM),

$$
\sum=\sum(\theta)
$$

$\sum=$ the population covariance matrix of the observed variables

$\sum(\theta)=$ the covariance matrix written as a function of the parameters for HIS use model

$\sum(\theta)=\left[\begin{array}{ll}\sum_{y y}(\theta) & \sum_{y x}(\theta) \\ \sum_{x y}(\theta) & \sum_{x x}(\theta)\end{array}\right]$

to solve for $Y$

$$
\begin{aligned}
& Y-B Y=\Gamma X+\varsigma \\
& (1-B) Y=\Gamma X+\varsigma \\
& Y=(1-B)^{-1}(\Gamma X+\varsigma) \\
& \sum_{y y}(\theta)=\operatorname{Cov}(Y, Y)=E\left[(Y-E Y)(Y-E Y)^{\prime}\right]
\end{aligned}
$$

$=E\left[(Y-E Y)\left(Y^{\prime}-E Y^{\prime}\right)\right]$

$=E\left[Y Y^{\prime}-E Y . Y^{\prime}+E Y E Y^{\prime}\right]$

$$
\begin{aligned}
& \sum_{y y}(\theta)=E\left(Y Y^{\prime}\right) \\
& \sum_{y y}(\theta)=E(1-B)^{-1}(\Gamma X+\varsigma)\left((1-B)^{-1}(X \Gamma+\varsigma)\right)^{1} \\
& = \\
& {\left[E(1-B)^{-1}(\Gamma X+\varsigma)\left(\Gamma^{\prime} X^{\prime}+\varsigma^{1}\right)(1-B)^{-1}\right]} \\
& = \\
& (1-B)^{-1}\left(E\left(\Gamma X^{\prime} X^{\prime} \Gamma\right)+E\left(\Gamma X E^{\prime}\right)+E\left(\varsigma X^{\prime} \Gamma^{\prime}\right)\right. \\
& \left.+E\left(\varsigma \varsigma^{\prime}\right)\right)(1-B)^{-1} \\
& \sum_{y y}(\theta)=(1-B)^{-1}\left(\Gamma \Phi \Gamma^{\prime}+\Psi\right)(1-B)^{-1} \\
& (9)
\end{aligned}
$$$$
\sum_{x x}(\theta)=\operatorname{Cov}(X, X)
$$$$
\text { (10) }
$$

$$
=E\left(X X^{\prime}\right)
$$$$
\Psi=E\left(X X^{\prime}\right)
$$$$
\sum_{x y}(\theta)=\operatorname{Cov}(X, Y)
$$$$
=E\left[(X-E X)(Y-E Y)^{\prime}\right]
$$$$
=E\left(X Y^{\prime}-Y^{\prime} E X-X E Y^{\prime}+E X E Y^{\prime}\right)
$$$$
=E X Y^{\prime}
$$$$
\sum_{x y}(\theta)=E\left(X\left(1-B^{-1}\right)(\Gamma X+\varsigma)^{\prime}\right)
$$$$
=E\left(X\left(X^{\prime} \Gamma^{\prime}+\varsigma^{\prime}\right)\left((1-B)^{-1}\right)\right)
$$$$
\sum_{x y}(\theta)=\Phi \Gamma^{\prime}(1-B)^{-1}
$$

$$
\begin{aligned}
& \sum_{y x}(\theta)=E\left(Y, X^{\prime}\right) \\
= & E\left[(1-B)^{-1}(\Gamma X+\varsigma) X^{\prime}\right] \\
= & (1-B)^{-1} E\left[\Gamma X X^{\prime}+\varsigma X^{\prime}\right] \\
= & (1-B)^{-1}\left[\Gamma E X X^{\prime}+E \varsigma E X^{\prime}\right]
\end{aligned}
$$




$$
\sum_{y x}(\theta)=(1-B)^{-1} \Gamma \Phi
$$

From equation (8), (9), (10), (11), and (12),

$$
\sum(\theta)=\left[\begin{array}{cc}
(1-B)^{-1}\left(\Gamma \Phi \Gamma^{\prime}+\Psi\right)(1-B)^{-1} & (1-B)^{-1} \Gamma \Phi \\
\Phi \Gamma^{\prime}(1-B)^{-1} & \Phi
\end{array}\right]
$$

\section{Model fitting}

The model fitting approach for the exploratory latent growth is similar to an approach often taken with growth mixture models. That is, models are fit with an increasing number of factors until one of the stopping rules is encountered. Models are compared using the Comparative Fit Index (CFI), Tuker-Lewis Index (TLI), and root mean square error of approximation (RMSEA). Also, comparatively, Bayesian Information Criteria (BIC), Sample Size Adjusted BIC (SSBIC) and chi-square are used for fit indexes. From the models, a model is selected as the best representation of the individual trajectories. From the selected model, different specifications can be examined by changing the location of fixed zero factor loadings and by fitting the selected model within the SEM using different rotation criteria.

With regards to [2] on rotation to smooth functions, there are two ways to specify the model with exploratory factors. One way is to specify fixing the factor loading for each of the factors and its variance. This specification will have the same model fit as the specification HIS use model because this is simply a representative of variables that could enhance HIS use. The other way, is to involve fixing $R-1$ fixed factor loadings to 0 for each variable and allowing the variables to correlate. Therefore, having a correlated variable is possible for HIS use model, which might be reasonable. Furthermore, [2][14][15][20] added that the trade-off comes in the form of additional fixed factor loadings - which might also constrain emergent interpretation of factor loading patterns. Although, this is reasonable in some cases, by specifying the model with uncorrelated factors which allow for the estimation of more variable loadings, which is similar to the Tuckerized curve approach.

In line with the goals and objectives mentioned earlier, this study intends to contribute in the following ways.

\section{Description of participants}

The total population of physicians in Nigeria is approximately 39,210 from the 36 states according to Nigerian Medical Association (NMA). In Lagos state, approximately 4,370 physicians are working at the 56 local government development areas in the state health care facilities. The health care workers in Lagos state are categorized as senior staff (medical officers of health, medical officers, staff nurses, pharmacists, and pharmacy technicians) and others (community health workers, community health officers, laboratory scientists, laboratory technicians, medical record officers, and medical record technicians). The population of the senior staff is 2,035 and the population of other health care workers is 2,335, and the aged range of each of these category is 20 years and above. In the senior staff category, a sample size of 100 or more will be selected from the total population of medical health officers which total population is 228, whereas in the medical officer's category, a sample size of at least 250 or more will be selected from the total population of medical officers which total population is 684 .

\section{Contribution}

Firstly, a theoretical contribution will be made by drawing on theories on information systems use and personal factors to develop an extended, replicable Unified Theory of Acceptance and Use of Technology (UTAUT). The Unified Theory of Acceptance and Use of Technology (UTAUT) will be extended with self-efficacy theory. The extended theory will be validated empirically and may be the lens for assessing physician's use of HIS in developing countries.

Secondly, a contextual contribution will be made by examining the concepts of user acceptance of technology and self-efficacy affect acceptance and use of technology. Also, this study will contribute in the context of HIS use in developing countries. This research is intended to contribute in this area of knowledge by adding to the literatures from the context of developing countries. Specifically, the contribution of this research will be from Nigeria context.

Thirdly, a methodological contribution will be made by providing a new approach to investigate factors influencing the usage of HIS by health care professionals in a developing country context. In addition, the validation of the conceptual research framework with structural equation modelling analysis will provide an informed approach to identify factors that are more influential to achieve successful use of HIS technologies.

Lastly, a practical contribution will be made by examining the factors for successful HIS usage which may influence health care professionals in their medical activities while using technology. This could also contribute to identifying vital human factors that can aid successful implementation of HIS technology. These factors can also enhance other information systems/technology implementation and usage. 
Although initial version of this paper has been presented at the i-society 2014 conference. The present study presents the research instrument (appendix 2) use for the fieldwork. In future publication the result of the fieldwork will be presented.

\section{Conclusion}

In this study, a theoretical model of HIS use and a mathematical model from the theoretical model have been presented. A case study where the exogenous and the endogenous factors can be evaluated through a mathematical model was considered. In future study, the validation of the proposed HIS model will be carried out through survey in a specific context whereby the model will be validated empirically. This reliability of the model after validation will rely largely on the sample size and the approach use unconstrained or latent moderated structural equations (LMS) for estimating the latent interaction effect of the variables in the model. The intended exploratory model from theory could be used in line with mathematical representation of the model to predict factors that could enhance the use of HIS by physicians.

\section{References}

[1] Ajzen, I. (1991). The theory of planned behavior, Organizational Behavior and Human Decision Processes, vol. 50, pp. 179-211.

[2] Arbuckle, J., and Friendly, M. L. (1977). On rotating to smooth functions. Psychometrika, 42, 127-140.

[3] Bagozzi, R. P.; Davis, F. D.; Warshaw, P. R. (1992). Development and test of a theory of technological learning and usage. Human Relations, 45(7): 660-686

[4] Bandura, A. (1986). Social Foundations of Thought and Action: A Social Cognitive Theory. Englewood Cliffs, N.J.: Prentice Hall.

[5] Bandura, A. (1999). Moral Disengagement in the Perpetration of Inhumanities. Personality and Social Psychology Review, 3(3), 193-209.

[6] Bandura, A. (1997). Self-Efficacy: The Exercise of Control. New York: W. H. Freeman

[7] Coenders, G., Batista-Foguet, J. M., and Saris, W. E. (2008). Simple, efficient and distribution-free approach to interaction effects in complex structural equation models. Quality and Quantity, 42, 369-396.

[8] Compeau, D. R. and Higgins, C. A. (1995b). Computer selfefficacy: Development of a measure and initial test. MIS Quarterly, 19(2) 189-211.

[9] Davis, F. D. (1989) Perceived usefulness, perceived ease of use, and user acceptance of information technology. MIS Quarterly, 13 (3), 318-346

[10] Fischer, S. and Smith, G. T. (2008). Binge eating, problem drinking, and pathological gambling: Linked by common pathways to impulsive behaviour. Personality and Individual Differences, 44, 789-800

[11] Fishbein, M. and Ajzen, I. (1975). Belief, attitude, intention, and behavior: An introduction to theory and research. Reading, MA: Addison-Wesley.
[12] Glasser, B. G., \& Strauss, A. L. (1967). The discovery of grounded theory. New York: Aldine

[13] Kailasam, S., Kumar, S., and Dharanipragada, J. (2010). Arogyasree: an enhanced grid-based approach to mobile telemedicine, International Journal of Telemedicine and Applications, 2.

[14] Lin, G. C., Wen, Z., Marsh, H. W., \& Lin, H. S. (2010). Structural equation models of latent interactions: Clarification of orthogonalizing and double-mean-centering strategies. Structural Equation Modeling, 17, 374-391.

[15] Marsh, H. W., Wen, Z., Nagengast, B., \& Hau, K.-T. (2012). Structural equation models of latent interaction. In R. H. Hoyle (Ed.), Handbook of structural equation modeling (pp. 436-458). New York, NY: Guilford.

[16] Mäenpää, T., Suominen, T., Asikainen, P., Maass. M., and Rostila, P. (2009). The outcome of regional healthcare information systems in health care: A review of the research literature. International Journal of Medical Informatics, 78, 757-771

[17] Moore, G. C. and Benbasat, I. (1991). Development of an instrument to measure the perception of adopting an information technology innovation, Information Systems Research, 2(3) 192-222

[18] Muthén, L. K., \& Muthén, B. O. (2010). Mplus: Users’ guide (Version 6.0). Los Angeles, CA: Muthén \& Muthén.

[19] Papadopoulos, H. (2010). Tile-Ippokratis: the experience of an eHealth platform for the provision of health care services in the Island of Chios and Cyprus, International Journal of Telemedicine and Applications-Special issue on healthcare applications and services in converged networking environments, 4.

[20] Ping, R. A., Jr. (1996). Latent variable interaction and quadratic effect estimation: A two-step technique using structural equation analysis. Psychological Bulletin, 119, 166-175.

[21] Stewart, T. (1986). Task fit, ease-of-use and computer facilities, Norwood, NJ: Ablex, pp. 63-76 In N. BjørnAndersen, K. Eason, \& D. Robey (Eds.), Managing computer impact: An international study of management and organizations.

[22] Szajna, B. (1994). Software evaluation and choice: predictive evaluation of the Technology Acceptance Instrument, MIS Quarterly, 18(3): 319-324.

[23] Thompson, R. L., Higgins, C. A., and Howell, J. M. (1991). Personal computing: Toward a conceptual model of utilization, MIS Quarterly, 15(1), 167-187

[24] Tornatzky, L. G.; Klein, R. J. (1982). Innovation characteristics and innovation adoption-implementation: A meta-analysis of findings, IEEE Transactions on Engineering Management, EM-29: 28-45.

[25] Tsang, S. (2012). Quantifying judicious use of health information technology. Journal of Evaluation in Clinical Practice, 19, 393-399.

[26] Venkatesh, V., Morris, M. G., Davis, G. B., Davis, F. D. (2003). User acceptance of information technology: Toward a unified view. MIS Quarterly, 27(3), 425-478.

[27] Wen, Z., Marsh, H. W., \& Hau, K.-T. (2010). Structural equation models of latent interactions: An appropriate standardized solution and its scale-free properties. Structural Equation Modeling, 17, 1-22.

[28] Yan, W., Wen, Z., Marsh, H. W., Hau, K. (2013). A comparison of strategies for forming product indicators for unequal numbers of items in structural equation models of latent interactions, Structural Equation Modeling. A Multidis . 


\section{Appendices}

Appendix 1: Definition of variables making up the theory

[26] definition of variables in UTAUT

\begin{tabular}{|c|c|c|c|c|c|}
\hline $\begin{array}{l}\text { Theory/ } \\
\text { Model }\end{array}$ & $\begin{array}{l}\text { Dependent } \\
\text { Variable } \\
\end{array}$ & $\begin{array}{l}\text { Independent } \\
\text { Variable } \\
\end{array}$ & Definition & Roots & Reference \\
\hline \multirow[t]{4}{*}{ UTAUT } & $\begin{array}{l}\text { Behavioral } \\
\text { Intention }\end{array}$ & $\begin{array}{l}\text { Performance } \\
\text { Expectance }\end{array}$ & $\begin{array}{l}\text { Performance expectancy is } \\
\text { the degree to which an } \\
\text { individual believes that } \\
\text { using the system will help } \\
\text { him or her to attain gains in } \\
\text { job performance. } \\
\text { (Venkatesh et al., 2003) }\end{array}$ & $\begin{array}{l}\text { BTAM/TAM2 } \\
\text { and } \\
\text { C-TAM-T }\end{array}$ & $\begin{array}{l}{[9] ;[23] ;} \\
{[17] ;[8]}\end{array}$ \\
\hline & & $\begin{array}{l}\text { Effort } \\
\text { Expectancy }\end{array}$ & $\begin{array}{l}\text { Effort expectancy is the } \\
\text { degree of ease associated } \\
\text { with the use of system }\end{array}$ & $\begin{array}{l}\text { TAM/TAM2; } \\
\text { MPCU and IDT }\end{array}$ & [9]; [17]; [23] \\
\hline & & $\begin{array}{l}\text { Social } \\
\text { Influence }\end{array}$ & $\begin{array}{l}\text { Social influence is the } \\
\text { degree to which an } \\
\text { individual perceives that } \\
\text { important others believe he } \\
\text { or she should use the new } \\
\text { system }\end{array}$ & $\begin{array}{l}\text { TRA; TAM2; } \\
\text { TPB/DTPB; } \\
\text { C-TAM-TPB; } \\
\text { MPCU and IDT }\end{array}$ & [9]; [17]; [23] \\
\hline & & $\begin{array}{l}\text { Facilitating } \\
\text { Conditions }\end{array}$ & $\begin{array}{l}\text { Facilitating condition is the } \\
\text { degree to which an } \\
\text { individual believes that an } \\
\text { organizational and technical } \\
\text { infrastructure exists to } \\
\text { support use of the system }\end{array}$ & $\begin{array}{l}\text { TPB/DTPB; C- } \\
\text { TAM-TPB; } \\
\text { MPCU and IDT }\end{array}$ & [9]; [17]; [23] \\
\hline
\end{tabular}

Appendix 2: Research instrument for fieldwork

\section{DAY MONTH}

Interview

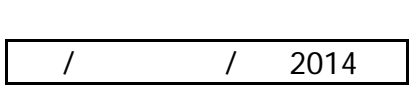

TIME STARTED

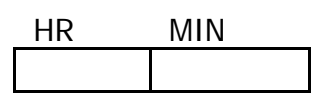

TIME COMPLETED

RESPONSE

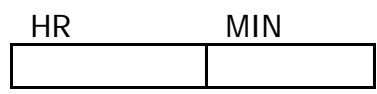

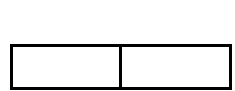

\section{RESPONSE CODES}

Completed questionnaire

Partially completed questionnaire

Not completed (specify reason)

$\begin{array}{ll}= & 01 \\ = & 02 \\ = & 03\end{array}$




\section{PART ONE}

\section{I am confident in using HIS when}

\begin{tabular}{|c|c|c|c|c|c|c|}
\hline & $\begin{array}{l}\text { Totally } \\
\text { Confide } \\
\text { nt }\end{array}$ & $\begin{array}{l}\text { Confide } \\
\text { nt }\end{array}$ & $\begin{array}{l}\text { Neither } \\
\text { agree } \\
\text { nor } \\
\text { disagree }\end{array}$ & $\begin{array}{l}\text { Not } \\
\text { Confident }\end{array}$ & $\begin{array}{l}\text { Not at all } \\
\text { Confident }\end{array}$ & $\begin{array}{l}\text { (Do not } \\
\text { know) }\end{array}$ \\
\hline $\begin{array}{l}\text { There was no one around to } \\
\text { tell me what to do as I use } \\
\text { HIS. }\end{array}$ & 5 & 4 & 3 & 2 & 1 & 8 \\
\hline I had never used HIS before. & 5 & 4 & 3 & 2 & 1 & 8 \\
\hline $\begin{array}{l}\text { I had only the HIS manuals } \\
\text { for reference. }\end{array}$ & 5 & 4 & 3 & 2 & 1 & 8 \\
\hline $\begin{array}{l}\text { I had seen someone else } \\
\text { using HIS before trying to } \\
\text { use it. }\end{array}$ & 5 & 4 & 3 & 2 & 1 & 8 \\
\hline $\begin{array}{l}\text { I could call someone for help } \\
\text { if I got stuck while using } \\
\text { HIS. }\end{array}$ & 5 & 4 & 3 & 2 & 1 & 8 \\
\hline $\begin{array}{l}\text { There is someone to help me } \\
\text { get stated using HIS. }\end{array}$ & 5 & 4 & 3 & 2 & 1 & 8 \\
\hline $\begin{array}{l}\text { I had a lot of time to } \\
\text { complete the job for which } \\
\text { HIS was provided. }\end{array}$ & 5 & 4 & 3 & 2 & 1 & 8 \\
\hline $\begin{array}{l}\text { I had the built-in help facility } \\
\text { for assistance while using } \\
\text { HIS. }\end{array}$ & 5 & 4 & 3 & 2 & 1 & 8 \\
\hline $\begin{array}{l}\text { There is someone showed me } \\
\text { how to use HIS first. }\end{array}$ & 5 & 4 & 3 & 2 & 1 & 8 \\
\hline $\begin{array}{l}\text { I had used similar software } \\
\text { similar to HIS to do the job. }\end{array}$ & 5 & 4 & 3 & 2 & 1 & 8 \\
\hline
\end{tabular}




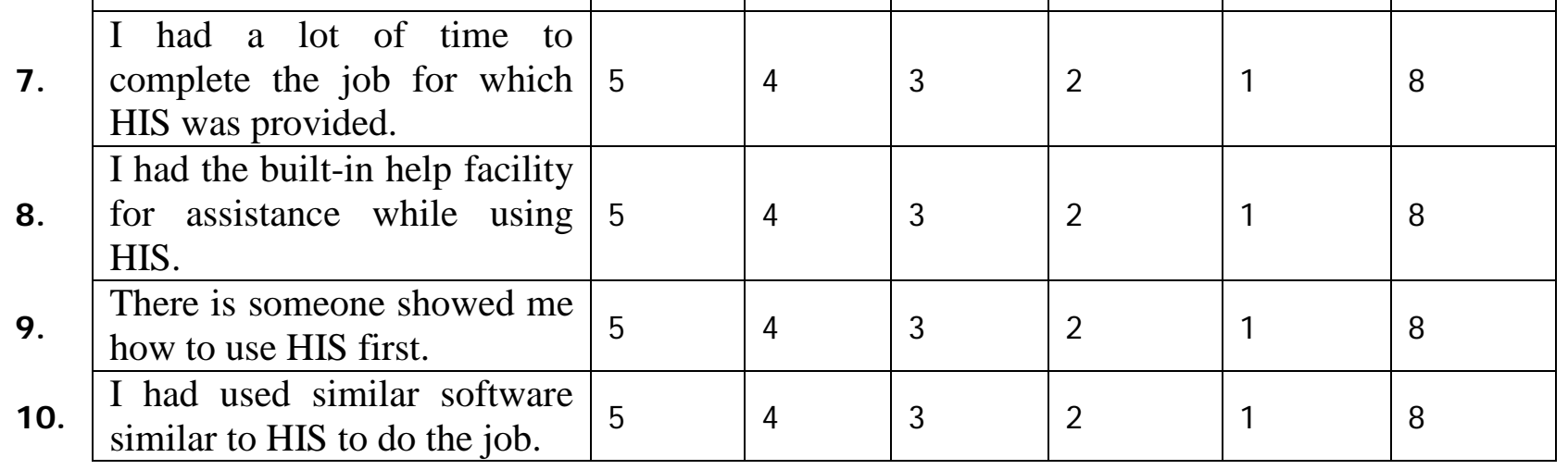

\section{PART TWO}

With regards to using HIS to what extent do you agree or disagree with the following statements?

11.

12.

\begin{tabular}{|l|l|l|l|l|l|l|}
\hline & $\begin{array}{l}\text { Strongly } \\
\text { Agree }\end{array}$ & Agree & $\begin{array}{l}\text { Neither } \\
\text { agree } \\
\text { nor } \\
\text { disagree }\end{array}$ & Disagree & $\begin{array}{l}\text { Strongly } \\
\text { disagree }\end{array}$ & $\begin{array}{l}\text { (Do not } \\
\text { know) }\end{array}$ \\
\hline $\begin{array}{l}\text { Enable me to accomplish } \\
\text { tasks more quickly }\end{array}$ & 5 & 4 & 3 & 2 & 1 & 8 \\
\hline Improve my performance & 5 & 4 & 3 & 2 & 1 & 8 \\
\hline Increase my productivity. & 5 & 4 & 3 & 2 & 1 & 8 \\
\hline Enhance effectiveness & 5 & 4 & 3 & 2 & 1 & 8 \\
\hline Make it easier to do my job. & 5 & 4 & 3 & 2 & 1 & 8 \\
\hline $\begin{array}{l}\text { HIS would be useful in my } \\
\text { job. }\end{array}$ & 5 & 4 & 3 & 2 & 1 & 8 \\
\hline
\end{tabular}

\section{PART THREE}

With regards to what extent do you agree or disagree with the following statements?

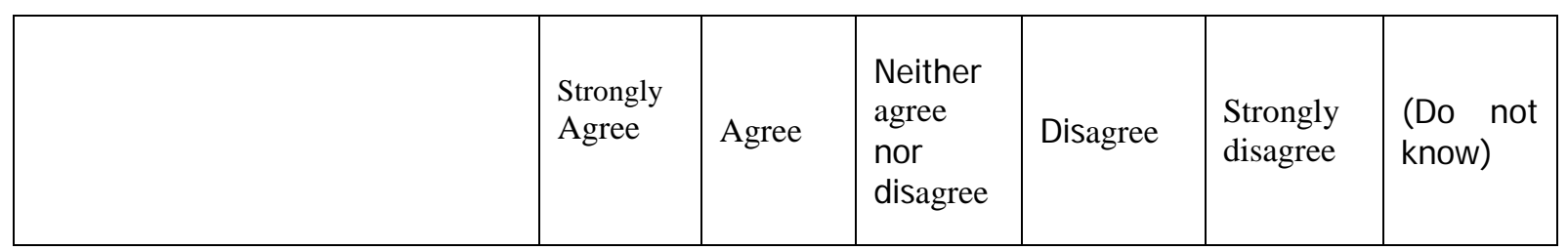




\begin{tabular}{|c|c|c|c|c|c|c|}
\hline & $\begin{array}{l}\text { Strongly } \\
\text { Agree }\end{array}$ & Agree & $\begin{array}{l}\text { Neither } \\
\text { agree } \\
\text { nor } \\
\text { disagree }\end{array}$ & Disagree & $\begin{array}{l}\text { Strongly } \\
\text { disagree }\end{array}$ & $\begin{array}{l}\text { (Do not } \\
\text { know) }\end{array}$ \\
\hline $\begin{array}{l}\text { Learning to use HIS would } \\
\text { be easy for me. }\end{array}$ & 5 & 4 & 3 & 2 & 1 & 8 \\
\hline $\begin{array}{l}\text { I would find it easy to get } \\
\text { HIS to do what I want it to } \\
\text { do. }\end{array}$ & 5 & 4 & 3 & 2 & 1 & 8 \\
\hline $\begin{array}{l}\text { I would understand how to } \\
\text { interact with HIS. }\end{array}$ & 5 & 4 & 3 & 2 & 1 & 8 \\
\hline Enhance effectiveness & 5 & 4 & 3 & 2 & 1 & 8 \\
\hline $\begin{array}{l}\text { I would find HIS to be } \\
\text { flexible. }\end{array}$ & 5 & 4 & 3 & 2 & 1 & 8 \\
\hline $\begin{array}{l}\text { It would be easy for me to } \\
\text { become proficient at using } \\
\text { HIS. }\end{array}$ & 5 & 4 & 3 & 2 & 1 & 8 \\
\hline I would find HIS easy to use. & 5 & 4 & 3 & 2 & 1 & 8 \\
\hline
\end{tabular}

\section{PART FOUR}

\section{With reference to what extent do you agree or disagree with the following statements?}

\section{4.}

\begin{tabular}{|l|l|l|l|l|l|l|}
\hline & $\begin{array}{l}\text { Strongly } \\
\text { Agree }\end{array}$ & Agree & $\begin{array}{l}\text { Neither } \\
\text { agree } \\
\text { nor } \\
\text { disagree }\end{array}$ & Disagree & $\begin{array}{l}\text { Strongly } \\
\text { disagree }\end{array}$ & $\begin{array}{l}\text { (Do not } \\
\text { know) }\end{array}$ \\
\hline $\begin{array}{l}\text { I would have the necessary } \\
\text { support to use HIS. }\end{array}$ & 5 & 4 & 3 & 2 & 1 & 8 \\
\hline $\begin{array}{l}\text { I would have the knowledge } \\
\text { necessary to use HIS. }\end{array}$ & 5 & 4 & 3 & 2 & 1 & 8 \\
\hline $\begin{array}{l}\text { HIS would be compatible } \\
\text { with other systems I use. }\end{array}$ & 5 & 4 & 3 & 2 & 1 & 8 \\
\hline $\begin{array}{l}\text { A specific person (or group) } \\
\text { would be available for } \\
\text { assistance with resolving HIS } \\
\text { difficulties. }\end{array}$ & 5 & 4 & 3 & 2 & 1 & 8 \\
\hline
\end{tabular}




\section{PART FIVE}

To what extent do you agree or disagree with the following statements?

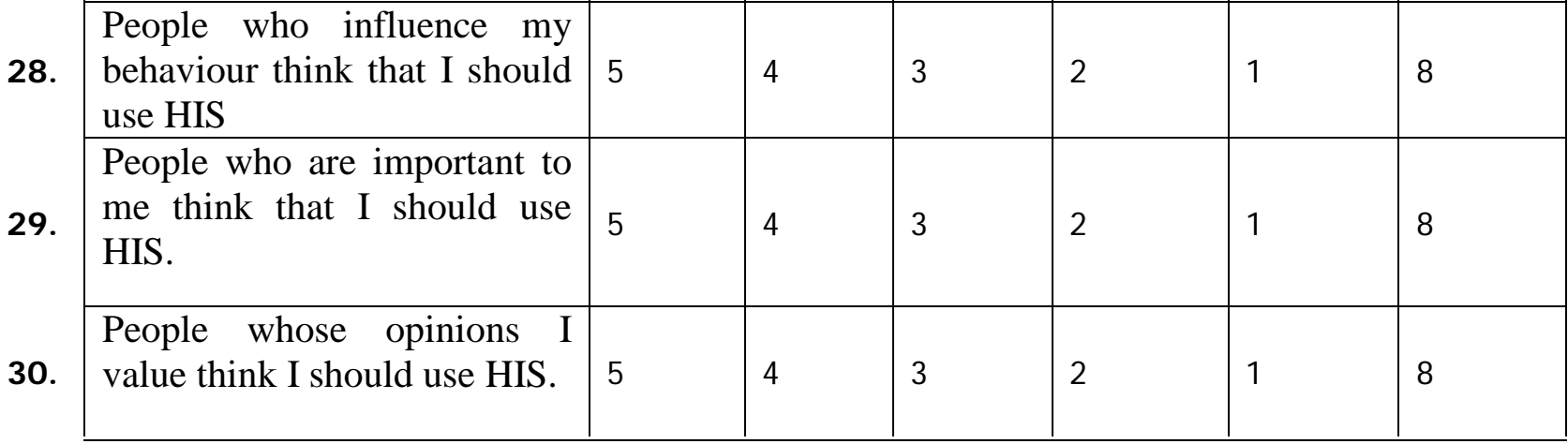

\section{PART SIX}

With reference to what extent do you agree or disagree with the following statements?

\begin{tabular}{|c|c|c|c|c|c|c|}
\hline & $\begin{array}{l}\text { Strongly } \\
\text { Agree }\end{array}$ & Agree & $\begin{array}{l}\text { Neither } \\
\text { agree } \\
\text { nor } \\
\text { disagree }\end{array}$ & Disagree & $\begin{array}{l}\text { Strongly } \\
\text { disagree }\end{array}$ & $\begin{array}{l}\text { (Do not } \\
\text { know) }\end{array}$ \\
\hline $\begin{array}{l}\text { I intend to use HIS, given the } \\
\text { opportunity. }\end{array}$ & 5 & 4 & 3 & 2 & 1 & 8 \\
\hline $\begin{array}{l}\text { I predict I would use HIS, } \\
\text { given the opportunity. }\end{array}$ & 5 & 4 & 3 & 2 & 1 & 8 \\
\hline $\begin{array}{l}\text { I plan to use HIS, given the } \\
\text { opportunity. }\end{array}$ & 5 & 4 & 3 & 2 & 1 & 8 \\
\hline
\end{tabular}




\section{RESPONDENT CHARACTERISTI CS}

1. Local government development area

2. Health care centre

3. Sex of respondent

\begin{tabular}{|l|l|}
\hline Male & 1 \\
\hline Female & 2 \\
\hline
\end{tabular}

4. Age of respondent in completed years [Age last birth day]

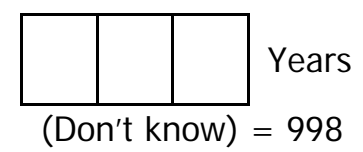

5. What is your Occupation/ Position (the name or title of your main job)?

INTERVIEWER: PROBE TO KNOW EXACTLY WHAT IS THE POSITION OF THE RESPONDENT IN THE HOSPITAL (DUTIES OR HIS/HER DAILY ACTIVITIES)

(Refused to answer) 97

(Don't know, inadequately described)

6. What is the highest level of education that you have ever completed?

\begin{tabular}{|l|l|}
\hline No schooling & 00 \\
\hline Primary Education & 01 \\
\hline Secondary Education & 02 \\
\hline Tertiary Education & 03 \\
\hline Other (Specify) & 97 \\
\hline (Do not know) & 98 \\
\hline
\end{tabular}

